\title{
Evaluation of Functionality and Growth Rates in Adrenal Incidentalomas: Single Center Experience
}

\author{
Adrenal İnsidentalomalarda Fonksiyonellik ve Büyüme Oranlarının Değerlendirilmesi: Tek Merkez Deneyimi
}

Suna Avci', (D) Yuksel Asli Ozturkmen², (D) Sayid Shafi Zuhur ${ }^{3}$, Gulkan Ozkan', (D) Elif Guven Cetin², iD Nazan Demir ${ }^{5}$, iD Yuksel Altuntas ${ }^{6}$

1- University of Health Sciences, Bursa Yüksek Ihtisas Health Training and Research Hospital, Department of Geriatric Medicine, Bursa Turkey. 2- University of Health Sciences, Istanbul Sisli Hamidiye Etfal Health Training and Research Hospital, Department of Internal Medicine, Istanbul, Turkey. 3- Namik Kemal University, Faculty of Medicine, Department of Endocrinology and Metabolism, Tekirdag, Turkey. 4- Adiyaman University Education and Research Hospital, Department of Hematology, Adiyaman, Turkey. 5- University of Eskisehir Osmangazi, Faculty of Medicine, Department of Medical Oncology, Eskisehir, Turkey. 6- University of Health Sciences, Istanbul Sisli Hamidiye Etfal Health Training and Research Hospital, Department of Endocrinology and Metabolism, Istanbul, Turkey.

\begin{abstract}
Objectives: In this study, we aimed to transfer observational data on incidentaloma cases, which we encountered in our center, in terms of their radiological, histopathologic features and hormonal activities, retrospectively review the growth rates during follow-up.

Material and Method: In this retrospective study 137 incidentaloma cases that met the inclusion criteria were analyzed. The medical records of all cases were analyzed statistically by recording age, sex information, hormonal examinations and imaging results, functional status of masses, histopathological findings, and information on adrenal mass diameter change during follow-up.

Results: In this study, 97 (71\%) patients were female and 40 (29\%) were male. 99 patients (72.3\%) were diagnosed with nonfunctional adenomas (NFA), 21 patients (15\%) with subclinical Cushing syndrome (SCS), 9 patients (6\%) with pheochromocytoma, 6 patients (4\%) with hyperaldosteronism, and 2 patients (1\%) with congenital adrenal hyperplasia (CAH). Patients with functional masses were significantly younger than patients with NFA (p: 0.04). Malignancy was identified in 6 patients (4\%). The mean followup period of the patients was $20.2 \pm 19.86$ months. Growth in mass size was detected in 24 patients (17\%). In 6 of the masses (26\% of the growing masses, $4 \%$ of all the masses), growth of over $1 \mathrm{~cm}$ was observed. The growth rate of the masses in male patients was significantly higher than the growth rate in female patients ( $p: 0.031$ ).

Conclusion: The incidence of mass growth and malignancy was higher in older age and male sex. Patient's age and sex should be bear in mind for their duration and frequency of follow-up in terms of functionality and malignant conversion.

ÖZET

Amaç: Bu çalışmada merkezimizde karşılaştı̆̆ımız insidentaloma vakalarının radyolojik, histopatolojik özellikleri ve hormonal aktiviteleri yönünden gözlemsel verilerini aktarmayl, takipleri esnasinda büyüme oranlarını retrospektif olarak incelemeyi amaçladık.

Gereç ve Yöntem: Dahil edilme kriterlerine uyan 137 insidentaloma vakaları retrospektif olarak incelendi. Tüm olguların medikal kayıtlarından yaş, cinsiyet bilgileri, hormonal tetkik ve görüntüleme sonuçlarl, kitlelerin fonksiyonellik durumları, histopatolojik bulguları ve takipleri boyunca adrenal kitle çapındaki değişim bilgileri kaydedilerek istatistiksel yöntemlerle analiz edildi.

Bulgular: Hastaların 97 'si (\%71) kadın, 40'ı (\%29) erkek idi. 99 (\%72.3) hastaya nonfonksiyonel adenom (NFA), 21 (\%15) hastaya subklinik Cushing sendromu (SCS), 9 (\%6) hastaya feokromasitoma, 6 (\%4) hastaya hiperaldosteronizm, 2 (\%1) hastaya konjenital adrenal hiperplazi (KAH) tanisl koyuldu. Fonksiyonel kitleye sahip olan hastalar anlaml olarak daha genç saptand $(p: 0,04)$. 6 (\%4) hastada

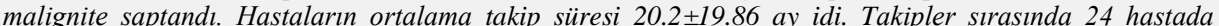
(\%17) kitle boyutunda büyüme saptandl. Kitlelerin 6'slnda (büyüyen kitlelerin \%26, tüm kitlelerin \%4 ü) 1 $\mathrm{cm}$ üzerinde büyüme görüldü. Erkek hastalardaki kitlelerin büyüme miktarı, kadın hastaların kitlelerdeki büyüme miktarlndan anlaml olarak daha yüksekti (p:0.031).

Sonuç: Kitle büyüme miktarı ve malignite görülme sıklı̆̆ ileri yaş ve erkek cinsiyette daha fazla saptanmıștır. Insidentalomaların fonksiyonellik ve malign dönüșüm açısından takibinde hastaların yașl ve cinsiyeti göz önünde bulundurulmalıdır.
\end{abstract}

\section{INTRODUCTION}

Adrenal incidentaloma (AI) is known as adrenal masses that are randomly detected during abdominal laparotomy or radiological examinations performed with various causes without the significant suspected adrenal disease (1). The mean prevalence of $\mathrm{AI}$ in
Keywords:

Adrenal,

Incidentaloma, Subclinical Cushing, Pheochromocytoma, Hyperaldosteronism, Adrenocortical Cancer.

Anahtar Kelimeler:

Adrenal,

Insidentaloma,

Subklinik Kuşing,

Feokromasitoma,

Hiperaldesteronizm, Adrenokortikal Kanser. $8.7 \%)(2)$. It has become one of the most common problems due to technological development and the widespread use of imaging methods. These masses which most of them are adenomas without functional features, may be potential lethal cancer or functional endocrine tumors. The first step to investigate these

Correspondence: Suna Avci, Department of Geriatric Medicine, University of Health Sciences, Bursa Yuksek Ihtisas Health Training and Research Hospital, Bursa Turkey. E-mail: sunavci012@yahoo.com

Cite this article as: Avcı S, Ozturkmen YA, Zuhur SS, Ozkan G, Cetin EG, Demir N, Altuntas Y. Evaluation of Functionality and Growth Rates in Adrenal Incidentalomas: Single Center Experience. Phnx Med J. 2020;2(3):125-132.
} 
Phnx Med J. November, 2020. Volume 2 No 3

Table 1: Comparison of adrenal insidentilomas by sex, age, size, localization and surgery rates

\begin{tabular}{|c|c|c|c|c|c|c|}
\hline \multirow{2}{*}{ Age (year) } & & \multicolumn{2}{|c|}{$\begin{array}{c}\text { Female } \\
\text { Mean } \pm \text { SD } / \text { n-\% }\end{array}$} & \multicolumn{2}{|c|}{$\begin{array}{c}\text { Male } \\
\text { Mean } \pm \text { SD/ n-\% }\end{array}$} & \multirow{2}{*}{$\begin{array}{c}\mathbf{p} \\
0.001\end{array}$} \\
\hline & & \multirow{2}{*}{\multicolumn{2}{|c|}{$\begin{array}{l}52.14 \pm 10.37 \\
24.66 \pm 10.37\end{array}$}} & \multicolumn{2}{|c|}{$57.85 \pm 12.13$} & \\
\hline \multirow[t]{2}{*}{ Size (mm) } & & & & & & \multirow[t]{2}{*}{0.747} \\
\hline & Right adrenal & 34 & $35.1 \%$ & 13 & $32.5 \%$ & \\
\hline \multirow[t]{2}{*}{ Localization } & Left adrenal & 44 & $45.4 \%$ & 19 & $47.5 \%$ & \multirow[t]{2}{*}{0.959} \\
\hline & Bilateral & 19 & $19.6 \%$ & 8 & $20.0 \%$ & \\
\hline \multirow{2}{*}{ Surgery } & Yes & 17 & $17.5 \%$ & 4 & $10.0 \%$ & \multirow{2}{*}{0.266} \\
\hline & No & 80 & $82.5 \%$ & 36 & $90.0 \%$ & \\
\hline
\end{tabular}

Student t test / Mann-whitney U/ Ki-square (Fischer test)

patients is to determine if the tumor is hormonally active with appropriate tests (3). Hormonally active secretory masses cause hyperaldosteronism, hyperandrogenism, Conn Syndrome, subclinical Cushing's syndrome (SCS), or pheochromocytoma with hormones they have secreted. After identification of subclinical cortisol release and the fact that they may pave the way for cardiovascular damage, studies on what to do for diagnosis and follow-up of AIs have been intensified (4).

In our study, we aim to retrospectively review the adrenal incidentaloma cases that were followed in our endocrinology outpatient clinic between 2008 and 2013 in terms of the incidence of adrenal incidentaloma cases, patient age, sex difference, mass size, mass location, radiologic features, pathologic diagnoses, functionalities and treatment approaches and growth rates of the growing masses during follow-up.

\section{MATERIAL AND METHOD}

Out of 158 patients who were referred from other centers to our endocrinology outpatient clinic between 2008 and 2013 due to incidentaloma diagnosis, 137 patients, who have visited for follow-up at least once after application and who have hormone and imaging examination results registered in the system, were investigated retrospectively. Helsinki international ethical rules were followed in the study; the study protocol was approved by the Ethics Committee of Şişli Etfal Training and Research Hospital (25.09.2012 number 94).

In our study, the cases with a mass size of $1 \mathrm{~cm}$ or more detected by Magnetic Resonance Imaging (MRI) and Ultrasonography methods, mostly by Computed Tomography (CT) taken for various reasons, were evaluated. All cases diagnosed by ultrasonography were evaluated with CT or abdominal MRI to finalize the diagnosis. The cases which are homogeneous and have smooth contours at computed tomography (CT), and whose density is 10 Hounsfield Units (HU) at unenhanced CT and $30 \mathrm{HU}$ and below at contrastenhanced CT were considered benign. Age, sex, mass localization, mass size, functionality status according to hormone examinations, change in mass size during follow-up, operation type, and histological findings of all the cases studied were retrospectively recorded.
Patients with known extra-adrenal malignancy, adrenal insufficiency, or Cushing's Syndrome were not included in the study.

Plasma normetanephrine and metanephrine levels in terms of pheochromocytoma, 24-hour normetanephrine and metanephrine excretion via urine, serum 17-alpha hydroxyprogesterone, androstenedione, DHEA-S, and total testosterone levels in the follicular phase in terms of hyperandrogenism, basal serum cortisol, and $1 \mathrm{mgr}$ dexamethasone suppression test (DST) for SCS screening, plasma aldosterone concentration, plasma renin activity and aldosterone (ng/dl)/renin (ng/ml/h) activity rate analyses performed to investigate the primary hyperaldosteronism in all hypertensive cases were examined to determine the hormonal state of the masses.

Mass specifics and histopathology results of the patients, who were referred to surgery or on whom a biopsy was done, were recorded. The growth in the mass was examined by recording information from the medical records of the patients, who have visited our center at least once for the recommended follow-up, out of the followed-up patients.

\section{Statistical Evaluation}

Mean, standard deviation, ratio, and frequency values were used in the descriptive statistics of the data. The distribution of the data was examined by the Kolmogorov Smirnov test. Independent-sample t-test and Mann-Whitney u test were used in the analysis of quantitative data. Chi-square test, and in case that chisquare conditions cannot be met, the Fischer test was used for the analysis of qualitative data. SPSS 21.0 program was used in the analyzes.

\section{RESULTS}

97 of the patients (71\%) were female and 40 (29\%) were male. The mean age of the patients was $53.8 \pm 10.8$ and the age of male patients was significantly higher than that of female patients (f: $52.1 \pm 9.3$, m: $57.9 \pm 12.1$ p: 0.001) (Table 1). It was detected that adrenal incidentalomas occurred most frequently between 51 and 60 (44\%) years of age in our patient group.

The average diameter of the masses was $24.66 \pm 10.37$ $\mathrm{mm}$ in female patients and $30.75 \pm 25.94 \mathrm{~mm}$ in male patients. Of the masses, 47 were located on the right 
Table 2: Distribution of functional and non-functional masses according to age, sex, localization, size and the rate of surgery

\begin{tabular}{|c|c|c|c|c|c|c|}
\hline \multirow{3}{*}{ Age (year) } & & \multicolumn{2}{|c|}{$\begin{array}{l}\text { Non-functional mass } \\
\text { Mean } \pm \text { SD } / \text { n- } \%\end{array}$} & \multicolumn{2}{|c|}{$\begin{array}{l}\text { Functional mass } \\
\text { Mean } \pm \text { SD/ n- } \%\end{array}$} & \multirow{2}{*}{$\begin{array}{c}\mathbf{p} \\
0.004\end{array}$} \\
\hline & & \multicolumn{2}{|c|}{$55.42 \pm 9.87$} & \multicolumn{2}{|c|}{$49.61 \pm 11.16$} & \\
\hline & Female & 69 & $69.7 \%$ & 28 & $73.7 \%$ & \multirow{2}{*}{0.646} \\
\hline Sex & Male & 30 & $30.3 \%$ & 10 & $26.3 \%$ & \\
\hline \multirow{3}{*}{ Localization } & Right adrenal & 37 & $37.4 \%$ & 10 & $26.3 \%$ & \multirow{3}{*}{0.453} \\
\hline & Left adrenal & 44 & $44.4 \%$ & 19 & $50.0 \%$ & \\
\hline & Bilateral & 18 & $18.2 \%$ & 9 & $23.7 \%$ & \\
\hline \multicolumn{2}{|l|}{ Size (mm) } & \multicolumn{2}{|c|}{$25.66 \pm 17.70$} & \multicolumn{2}{|c|}{$28.47 \pm 13.49$} & 0.088 \\
\hline \multirow{2}{*}{ Surgery } & Yes & 4 & $4 \%$ & 17 & $44.7 \%$ & \multirow{2}{*}{0.0001} \\
\hline & No & 95 & $96 \%$ & 21 & $55.3 \%$ & \\
\hline
\end{tabular}

Student t test / Mann-whitney U/ Ki-square (Fischer test)

adrenal gland (34.3\%) and 63 were located on the left adrenal gland (46\%), while 27 (19.7\%) were bilaterally localized. Masses were operated on in $17.5 \%$ of the female patients and $10 \%$ of the male patients. The diameter width of the masses in male and female patients, the localization of masses, and the rate of operating on the masses did not differ significantly ( $\mathrm{p}>$ 0.05) (Table 1).

The masses were detected by computerized tomography (CT) in 53 patients (38.7\%), by magnetic resonance imaging (MRI) in 38 patients (27.7\%), and by Ultrasonography (USG) in 46 patients (33.6\%). All of the masses detected by USG were reevaluated by CT or MR. 35 patients (25.5\%) were examined by PET-CT due to the suspected malignancy.

When the hormonal functionality of the masses was assessed, 99 patients (72.3\%) were detected to have non-functioning adenoma (NFA) (69 of them (69.7\%) were females, 30 (30.3\%) were males). It was detected that 21 patients (15\%) had Subclinical Cushing Syndrome (SCS) (17 females (81\%) and 4 males had Hyperaldosteronism (3 females (50\%) and 3 males (50\%)), 2 patients (1.4\%) had CAH (1 female and 1 male) (Graphic 1). It was detected that the mean age of the patients with functional mass was $49.6 \pm 11.16$ and the mean age in NFA was 55.4 \pm 9.87 . The mean diameter of the patients with NFA was $25.6 \pm 17.7 \mathrm{~mm}$, while that of those with functional adenomas was detected to be $28.4 \pm 13.4 \mathrm{~mm}$. The localization distribution and diameter width ( $>>0.05$ ) of nonfunctional masses and functional masses did not differ. Patients with functional mass were found to be significantly younger than patients with NFA (p: 0.04). On the other hand, no significant difference was found between the sex distribution ( $p>0.05$ ) (Table 2)

In our study, pathologic sampling by FNAB was performed in 29 patients (21\%) and adrenalectomy was performed in 21 patients (15\%). Out of the patients who received the surgical treatment, 17 (81\%) were females (mean age: 48.6 \pm 12.1 ) and 4 (19\%) were males (mean age: $45 \pm 6.5$ ). The age of the patients in the group that underwent an operation was significantly

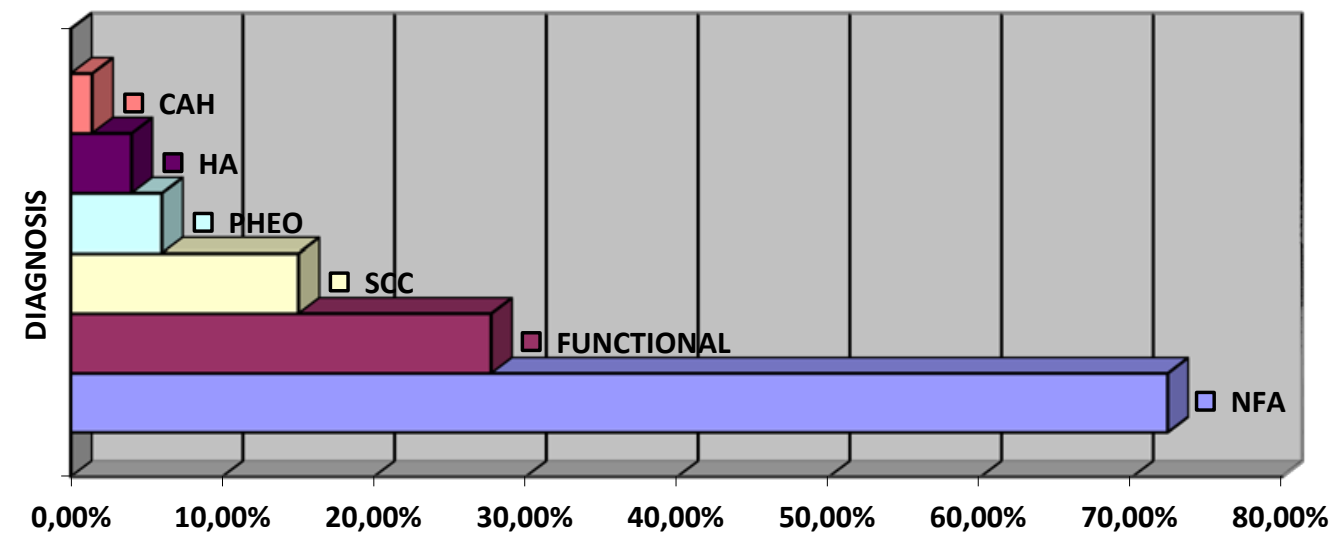

NFA: Non-functional adenoma, SCC: Subclinical Cushing Syndrome, PHEO: Pheocromcytoma, HA: Hyperaldosteronism,

CAH: Congenital adrenal hyperplasia

Graphic 1: Distribution of adrenal incidentalomas according to functionality

(19\%)), 9 patients (6\%) had Pheochromocytoma (7 females (77.8\%) and 2 males (22.2\%)), 6 patients (4\%) lower (p: 0.05) than in the group that did not undergo an operation. The diameter average of the operated 
masses was measured as $32.2 \pm 17.4 \mathrm{~mm}$. No significant difference was found in sex distribution, tumor diameter values, localization of tumors, growth status ( $p>0.05$ ) in patients who underwent or did not undergo an operation. Surgery was performed on 4 of the patients with NFA (4\%) and 17 of the patients with functional mass $(44.7 \%)$. The size of the surgically treated NFA was detected to be $41.7 \pm 1.36$ (max. 43.3) and it was observed that no malignancy was detected in any of them.

When histopathologic results were evaluated, malignancy was identified in 6 patients (4\%), 2 of whom had adrenocortical carcinoma, 4 of whom had a metastatic lesion. 2 of the metastatic lesions were lung cancer, one was renal cell carcinoma (RCC) and the other was Non-Hodgkin's Lymphoma (NHL) metastasis. Malignancy was found to be 5 times more common in males than females. It was seen that $50 \%$ of the patients with malignancy detected were in the 6th decade age group and $50 \%$ of them were in the 7 th decade age group. $54.8 \pm 7.1$ ). 2 of the patients in the malignancy group (33.3\%) were localized in the right adrenal, 1 (16.7\%) was localized in the left adrenal and 3 (50\%) were bilaterally located. The mean diameter of these 6 masses was $60 \pm 51.4 \mathrm{~mm}$, and it was detected that the smallest mass was $15 \mathrm{~mm}$ and the largest mass was $130 \mathrm{~mm}$ (Table 3).

Table 3: Evaluation of malign masses which detected in patients with adrenal incidentaloma

\begin{tabular}{llcc}
\hline & & \multicolumn{2}{c}{ Malignancy } \\
& & \multicolumn{2}{c}{$54.83 \pm 7.19$} \\
\hline Age & Female & 1 & $16.7 \%$ \\
\hline Sex & Male & 5 & $83.3 \%$ \\
Size (mm) & & $60.00 \pm 51.48$ \\
\hline Localization & Left & 1 & $16.7 \%$ \\
& Bight & 2 & $33.3 \%$ \\
& & 3 & $50.0 \%$ \\
\hline Student $t$ test/Ki-square & &
\end{tabular}

The mean follow-up period of the patients was 20.2 \pm 19.86 months (min: 8.7 max: 31.6). Out of 24 patients $(17 \%)$ in whom a growth in mass diameter has been detected during the follow-up in our study, 22 patients $(91 \%)$ were in the 5 th decade and above. The growth amount in all patients was $11 \mathrm{~mm}$ on average. Average mass growth detected in the 4th decade in these patients was found to be $5 \mathrm{~mm}, 12 \mathrm{~mm}$ in the 5 th

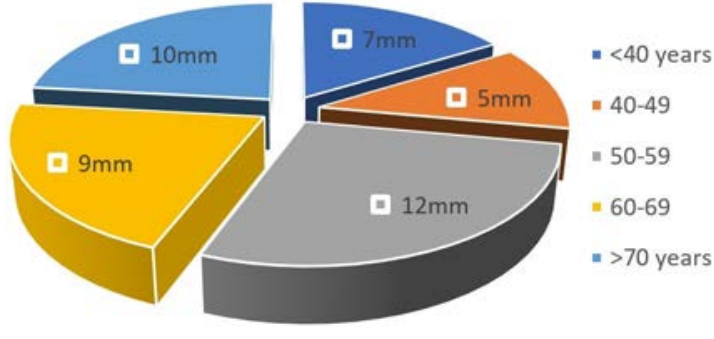

Graphic 2: Distribution of size enlargement rates of adrenal incidentalomas according to patient's age on follow up period

decade, $9 \mathrm{~mm}$ in the 6th decade, and $10 \mathrm{~mm}$ in the 7th decade (Graphic 2). During the follow-ups, a growth over $1 \mathrm{~cm}$ (26\% of the growing masses and $4 \%$ of all masses) has been observed in 6 of the masses and 3 of them were operated on.

Growth was detected in 19 (19\%) of the existing masses in female patients, and in $5(12 \%)$ of the existing masses in the male patients. 10 (52\%) of the growing masses in female patients were localized in the right adrenal, 9 (47\%) in the left adrenal; 3 (60\%) of the growing masses in male patients were localized in right adrenal and 2 (40\%) in left adrenal. The average growth of masses in female patients was $10.4 \pm 9.2 \mathrm{~mm}$, whereas it was detected to be $12 \pm 2.0$ $\mathrm{mm}$ in male patients. The localization of the growing mass and the growth rate of the mass did not differ significantly ( $p>0.05)$ during follow-ups in male and female patients. The growth amount of the masses in male patients was significantly higher (p: 0.031) than that of masses in female patients (Table 4).

When the growing masses were evaluated according to their functions during the follow-ups, it was detected that $20 \%$ (20\%) of the NFAs and $4 \%(10.5 \%)$ of the functional masses grew. Of these growing masses, 11 (55\%) of the NFA were localized on the right side and 9 (45\%) on the left side, while $2(50 \%)$ of the functional masses were localized on the right side and the other 2 on the left side. NFAs were found to grow by a mean of $10.8 \pm 8.92 \mathrm{~mm}$, while functional adenomas were found to grow by $10.75 \pm 4.35 \mathrm{~mm}$. The "growth rate" of NFA and functional groups, "localization of growing mass", "growth amount" did not differ significantly ( $\mathrm{p}>0.05)$.

\section{DISCUSSION}

The incidence of adrenal incidentalomas has increased by the prolongation of the life span and the increased use of diagnostic imaging tests. The mean prevalence of $\mathrm{AI}$ in autopsy series was reported to be around $2 \%$ $(1.0-8.7 \%)$. In radiological studies, the prevalence of $\mathrm{AI}$ is $3 \%$ in middle-aged individuals and reaches to over $10 \%$ in elderly adults (2). 
Table 4: Evaluation of growing masses according to patient's sex.

\begin{tabular}{|c|c|c|c|c|c|c|}
\hline \multirow{4}{*}{ Enlargement } & \multicolumn{5}{|c|}{ Sex } & \multirow[b]{2}{*}{$\mathbf{p}$} \\
\hline & & \multicolumn{2}{|c|}{$\begin{array}{c}\text { Female } \\
\text { Mean } \pm \text { SD } / \text { n-\% }\end{array}$} & \multicolumn{2}{|c|}{$\begin{array}{c}\text { Male } \\
\text { Mean } \pm \text { SD/n-\% }\end{array}$} & \\
\hline & Yes & 16 & $19.5 \%$ & 8 & $14.5 \%$ & \\
\hline & No & 66 & $80.5 \%$ & 47 & $85.5 \%$ & 0.453 \\
\hline \multirow[t]{2}{*}{ Localization } & Right & 9 & $56.3 \%$ & 4 & $50.0 \%$ & \multirow{2}{*}{0.772} \\
\hline & Left & 7 & $43.8 \%$ & 4 & $50.0 \%$ & \\
\hline $\begin{array}{l}\text { Amount of } \\
\text { enlargement }(\mathrm{mm})\end{array}$ & & \multicolumn{2}{|c|}{$10.47 \pm 9.26$} & \multicolumn{2}{|c|}{$12.00 \pm 2.00$} & 0.55 \\
\hline
\end{tabular}

In many studies, the incidence of adrenal incidentaloma is higher in female patients than males $(5,6)$. However, it appears that there are racial differences in this issue. In Far Eastern-originated studies, incidentaloma was found to be more frequent in the male population $(7,8)$ In our study, $71 \%$ (97 patients) were females and $29 \%$ (40 patients) were males, which is similar to western-originated studies.

Although the association between adrenal mass incidence and age is expressed at different rates in different studies, it is observed that as the age increases, the mass incidence increases significantly. In a study in 2003, Tao et al. reported that adrenal mass prevalence was higher in the 5th and 6th decades (9). Bin et al. found an average age of 48.5 in 152 disease series, while Çömlekçi et al. found that the mean age was 54.7 years in 376 disease series $(6,7)$. Similar to the literature, the incidence of incidentaloma has increased with the age up to the sixth decade in our study. The mean age of our patients was $53.8 \pm 10.8$, whereas the incidentaloma was found the most frequently in the fifth decade (60 patients, $40 \%$ ). This situation can be explained by the age-related ischemic damage and atrophy-induced cortical compensatory hyperplasia (10). It should also be remembered that performing more examination in the middle and old ages for various reasons is an effective factor for the increase in the observation frequency of the mass.

Previous studies have shown that the majority of incidentalomas are hormonally nonfunctional. NFA prevalence is $69 \%$ in surgical series and about $75 \%$ in series containing all adrenal incidentalomas (2). NFA was found to be $71.3 \%$ in the 1005 disease series of Montero et al. and $73 \%$ in 376 disease series reported by Çömlekçi et al. from Turkey $(5,6)$ In our study, NFA was found the most frequently by the literature (99 patients, 72\%).

What should be done firstly in patients with mass detected in adrenal glands is to evaluate whether or not the mass is hormonally active. Hormone tests should be performed on all patients to detect the silent pheochromocytoma that may be a potential cause of death and the SCS cases that can lead to adrenal crisis under acute stress conditions by suppressing the other adrenal gland. It is recommended to start assessing the functional status of the masses by investigating whether there is autonomous cortisol release (11).
The prevalence of SCS varies between 5\% and 20\% depending on the difference of the diagnostic criteria in the literature, the number of patients included in the studies, and the selected patient population $(12,13,14)$. SCS prevalence was found to be $9.2 \%$ in the 1004 largest adrenal incidentaloma disease series performed by Mantero et al. and $4.7 \%$ in Bülow's study $(5,15)$ In our study, SCS was found to be $15 \%$ in compliance with the literature.

Patients with SCS are thought to be exposed to damaging effects of hypercortisolism, less often than Cushing's Syndrome. It is emphasized that SCS may play a role in the development of cardiovascular and metabolic diseases (hypertension, obesity, insulin resistance, and Metabolic Syndrome), especially in the elderly by impairing subclinical cortisol autonomy (16). In the European Society of Endocrinology Clinical Practice Guideline (ESEC), screening of all SCS cases in terms of HT and DM is suggested (2). Diagnosis of SCS in the pre-symptomatic period and the early-term treatment of metabolic and cardiovascular diseases such as atherosclerosis, hypertension, diabetes, obesity will increase the quality of life of patients.

Clinically silent pheochromocytoma with a prevalence of $1.5-14 \%$ in patients with AI is not uncommon (17). In the studies with large series, pheochromocytoma ranks second in the prevalence list with a rate of $4.2 \%$ (5). In our study, pheochromocytoma is the second most common functional mass after SCS with a rate of $6 \%$ (9 patients). Pheochromocytoma, which is detected at a rate of approximately $0.001-0.1 \%$ in patients with hypertension, causes diagnostic difficulties because a large portion does not occur with the classic triad (18). Mannelli et al. reported that the duration of diagnosis in patients is over three and a half years and in extreme cases, these periods may extend up to 30 years (19). Given the diagnostic difficulties, it is necessary to routinize the screening of the patients for pheochromocytoma, even if they do not show an obvious clinical presentation when performing the hormonal evaluation of all patients with adrenal incidentaloma.

When the adrenal mass is detected, all patients with hypertension should be screened for primary aldosteronism regardless of serum potassium level. Bernini et al. reported that aldosteronoma accounted 
for a portion of $5.5 \%$ of the adrenal incidentalomas (20). In our study, all hypertensive patients were included in the study, regardless of the potassium level, and hyperaldosteronism was detected at a frequency level of $4 \%$.

In our study, functional and non-functional masses were compared in terms of age, sex, tumor diameter, and tumor localization. As a result of this comparison, functional groups were found to be detected at an earlier age than non-functional groups. No significant differences could be shown for other parameters. In compliance with our study, Çömlekçi et al. found that the mean age of patients with functional masses was lower than that of NFA patients (6). This may be because patients with functional masses are more likely to be exposed to health screening due to their phenotypic and cardiometabolic characteristics.

When AI is detected, one of the first things to do is the determination of functionality and the other one is the malignant/benign mass distinction. Imaging methods are often guiding in this respect. The masses, which are homogeneous and have smooth contours at CT and whose density is 10 Hounsfield Unit (HU) and lower at unenhanced $\mathrm{CT}$, are considered benign (sensitivity: $>90 \%$, specificity: $50-100 \%$ ) (2). MRI is recommended in cases where there is no clear separation by BT. During MRI imaging, the masses that are detected to be hypo- or isointense concerning liver in T1-weighted images and hyper- or isointense in T2-weighted images are considered benign (21). Additional imaging methods such as PET CT can be performed in incidentalomas that seem suspicious in imaging methods. In case of low suspicion, CT or MRI evaluation may be considered again after 6 months, or the operation may be planned without delay if there is a high suspicion. The biopsy is a more useful method for differentiating between metastasis and incidentaloma, especially in patients who are known to be cancer (22). The following three criteria must be considered when planning the FNAB; It should be clear that the mass is non-functioning, there should not be an exact malignant/benign differentiation of the mass with other methods and the fact that the histological type of the mass is known should have a guiding effect in mass management (2). Adrenalectomy is required for final diagnosis and treatment in masses that cannot be distinguished from FNAB either. The 2016 ESEC guideline recommends operation for the unilateral masses with hormone release at the clinically significant level, regardless of their sizes. Although no consensus could be reached for masses over $6 \mathrm{~cm}$, it is advocated that the surgery should be prioritized. For masses between 4 to $6 \mathrm{~cm}$, surgery decisions should be made according to patient-specific assessments and additional evidence. Open surgery is recommended for the masses over $6 \mathrm{~cm}$, while laparoscopic adrenalectomy is recommended for the masses under 6 $\mathrm{cm}$ which are suspected to be malignant, but for which no local invasion is suspected. Open surgery is recommended in all sizes if local invasion findings are present (2).

In our study, 21 patients with the masses $\geq 4 \mathrm{~cm}$ and the functional masses regardless of their size were referred to surgery (4 are NFA, 17 are functional). The mean diameter of the masses referred to as the surgery was found to be $32.2 \pm 17.4 \mathrm{~mm}$. Four of them were NFA and 17 were functional adenomas. The sizes of the NFAs referred to surgery due to their sizes were $41.7 \pm 1.36$ (max. 43.3) and no malignancy was detected in any of them. The mean mass diameter of the 6 patients, in whom malignancy was detected (2 adrenocortical carcinomas, 4 metastatic lesions), was found to be $60 \mathrm{~mm}$ (range between 15 and $130 \mathrm{~mm}$ ). Similarly to our study, malignancy cases that are reported to be under $4 \mathrm{~cm}$ were also found in the literature research $(7,15,23,24)$. No comment could be made on specificity/sensitivity of 4-cm cut-off value as our study is NFA and the number of cases referred to surgery is low. However, the fact that no malignancy was detected in any of the cases and that the average size of the malignant cases was found to be around 6 cm supports the current literature.

The incidence of malignancy was found to be $4 \%$ in our study, and similarly, in the literature, adrenal malignancy prevalence was found to be $5.8 \%$ by Mantero et al. and $4.8 \%$ by Çömlekçi et al. $(5,6)$. The rate of the metastatic adrenal tumor was reported to be $2 \%$ by Mantero et al. and $1.5 \%$ by an extensive Korean study $(5,8)$.

Adrenal incidentalomas should be monitored in terms of hormonal hypersecretion and malignant transformation after initial evaluation. However, to avoid unnecessary imaging and hormone testing during follow-up, it is necessary to determine which patients and how often the follow-up should be performed. Guides are updated in this regard in the light of studies done. In the American Association of Clinical Endocrinologists (AACE) guidelines, which was published in 2009, radiological follow-up was initially recommended in patients, who did not meet the surgical criteria fully, after 3 to 6 months and then yearly, and it was emphasized that hormonal evaluations should be performed annually for the first 5 years after diagnosis (25). In the 2016 ESEC guide, however, follow-up is not recommended with additional imaging for masses below $4 \mathrm{~cm}$, which are found clearly to be benign in imaging and laboratory examinations. Monitoring the suspected masses using unenhanced CT or MRI during the period of 6 to 12 months is recommended and, for those with a growth detected to be more than $5 \mathrm{~mm}$ or $20 \%$ of the maximum diameter within this period, surgical resection is recommended. In case that growth under these limits is detected, follow-up should be performed after 6-12 months again using imaging. Hormonal level measurement is not recommended in patients whose initial hormonal activity is detected to be normal and for whom no clinical finding that will suggest hormone production during the follow-up is found. Annual 
hormonal and metabolic evaluation is recommended for SCSs.

In our study, the mean follow-up period was 20.2 \pm 19.86 months (min: 8.7, max: 31.6) and growth in masses in $23(16 \%)$ of the patients was found, the mean growth amount of which was $11 \mathrm{~mm}$. In 6 of them (26\% of growing masses, $4 \%$ of all masses), growth of more than $1 \mathrm{~cm}$ was observed during the follow-ups and 3 masses were operated. Out of them, a female patient with a tumor size of $15 \mathrm{~mm}$ underwent an operation because the tumor diameter was found to be $60 \mathrm{~mm}$ at the end of a one-year follow-up and her pathologic diagnosis was adrenocortical carcinoma. The pathology of the other 2 masses was found to be compatible with the adenoma. It has been shown during the follow-ups that only 5-20\% of AI grows more than $1 \mathrm{~cm}$, mainly in the first 3 years $(11,26,27,28,29)$. Bülow et al. found growth of more than $0.5 \mathrm{~cm}$ in $17(7 \%)$ patients and a growth of more than $1 \mathrm{~cm}$ in 12 (5\%) patients in 299 disease series that they followed for 25 months (29). Studies showed that shrinkage was found in tumors in some cases during the follow-ups, which was associated with cystic deformation and apoptosis in the mass (26). Also in our study; for two cases diagnosed with $\mathrm{CAH}$, the masses were observed to shrink after the treatment given during the follow-ups whereas no shrinkage was found in NFA, functional adenomas, and pheochromocytomas.

As in the study by Çömlekçi et al. many follow-up studies have shown that the diameters of the mass remain stable in young patients, while the growth rate of tumor diameter increases especially in middle and advanced ages (6,30). In fact, in our study; 91\% (22 patients) of patients with adrenal incidentaloma, the diameter of which was detected to be grown during the follow-up, were 5 th decade or older. The average growth amount was $5 \mathrm{~mm}$ in the 4th decade, $12 \mathrm{~mm}$ in the 5th decade, and $9 \mathrm{~mm}$ in the 6th decade. This growth may be attributed to the decrease in adrenocortical thickness and increase in microhemorrhages in the tumor with increasing age, as well as the increase in malignancy frequency with increased genetic breakdown after the 5th decade.
During the follow-ups, growth was observed in 19\% (19 patients) of the masses present in female patients and $12 \%$ (5 patients) masses in male patients. The mean growth amount of the growing masses in female patients was found to be $10.4 \pm 9.2 \mathrm{~mm}(61.2 \pm 65.9 \%)$, whereas the growth amount of masses in male patients was found to be $12 \pm 2 \mathrm{~mm}(51.8 \pm 14.8 \%)$. The growth amount of the masses in male patients was significantly higher $(p<0.05)$ than that of masses in female patients. To the best of our knowledge, no studies are investigating the relationship between growth amount and sex in previous studies. There is a need for studies with extensive series as well as long-term follow-up studies to investigate the contribution of the male sex to the amount of growth in AI patients. In our study, there was no significant difference $(p>0.05)$ in "localization of the growing mass" and "the amount of growth" between non-functional and functional masses. Similarly to our study, Libe et al. also found that non-functional and functional masses exhibited similar growth rates during their follow-ups (31).

There is a wide cumulative risk range from $7 \%$ to $47 \%$ at the end of 5 years regarding the progression of the nonfunctional masses to functional masses (32). While the development of evident CS during the follow-ups is a risk of $<1 \%$, SCS development can be observed to be around $10 \%$ (14). Since our study was conducted in the form of retrospective data scanning, the rate of conversion of nonfunctional masses to functional ones was not recorded. This is one of our study limitations.

Conclusion: Distribution of adrenal masses according to age and sex, and functionality ratios were found similar to the existing literature in our center. The mass growth amount and malignancy detection rate are higher in the older age group. The mass growth amount was significantly higher in the male sex than in the female sex, and there is a need for prospective studies with extensive series in this regard. The relevant guidelines on the follow-up durations of incidentalomas, the place of mass growth amount in the benign/malignant mass distinction, and the operation indications are constantly updated in the context of the information provided by clinical trials. We believe that the observational data we have shared from our Center will contribute to the literature for further guidelines.

Source of Finance

During this study, no financial or spiritual support was received neither from any pharmaceutical company that has a direct connection with the research subject nor from a company that provides or produces medical instruments and materials which may negatively affect the evaluation process of this study.

Conflicts of Interest

There is no conflict of interest in connection with this paper.

\section{REFERENCES}

1. Kloos RT, Gross MD, Francis IR, Korobkin M, Shapiro B. Incidentally discovered adrenal masses. Endocr Rev 1995;16(4):460-84.

2. Fassnacht M, Arlt W, Bancos I, Dralle H, Newell-Price J, Sahde A, et al. Management of adrenal incidentalomas: European Society of Endocrinology Clinical Practice Guideline in collaboration with the European Network for the Study of Adrenal Tumors. Eur J Endocrinol. 2016;175(2): G1-G34. 


\section{Avci et al.}

3. Pantalone KM, Gopan T, Remer EM, Faiman C, Ioachimescu AG, Levis HS et al. Change in adrenal mass size as a predictor of a malignant tumor. Endocr Pract. 2010;16(4):577-587.

4. Mazzuco TL, Bordeau I, Lacroix A. Adrenal incidentalomas and subclinical Cushing's syndrome: diagnosis and treatment. Curr Opin Endocrinol Diabetes Obes 2009;16(3):203-10.

5. Mantero F, Terzolo M, Arnaldi G, Osella G, Masini AM, Ali A et al. A survey on adrenal incidentaloma in Italy. Study Group on Adrenal Tumors of the Italian Society of Endocrinology. J Clin Endocrinol Metab 2000;85(2):637-644.

6. Comlekci A, Yener S, Ertilav S, Seçil M, Akinci B, Demir T, et al. Adrenal incidentaloma, clinical, metabolic, follow-up aspects: single centre experience. Endocrine. 2010;37(1):40-6.

7. Bin X, Qing Y, Linhui W, Li G, Yinghao S. Adrenal incidentalomas: experience from a retrospective study in a Chinese population. Urol Oncol. 2011;29(3):270-4.

8. Ahn SH, Kim JH, Baek SH, Kim H, Cho YY, Suh S, et al. Characteristics of adrenal incidentalomas in a large, prospective computed tomography-based multicenter study: the COAR study in Korea. Yonsei Med J. 2018;59(4):501-510.

9. Tao H, Lu ZL, Li HZ. A clinical analysis of 103 cases of adrenal incidentaloma. Zhongguo Yi Xue Ke Xue Yuan Xue Bao. 2003;25(2):172-5.

10. Dobbie JW. Adrenocortical nodular hyperplasia: the ageing adrenal. J Pathol. 1969;99(1):1-18.

11. Terzolo M, Stigliano A, Chiodini I, Loli P, Furlani L, Arnaldi G et al. AME position statement on adrenal incidentaloma. Eur J Endocrinol 2011;164(6):851-870.

12. Mcleod MK, Thompson NW, Gross MD, Bondeson AG, Bondeson L. Sub-clinical Cushing's syndrome in patients with adrenal gland incidentalomas. Pitfalls in diagnosis and management. Am Surg. 1990;56(7):398-403.

13. Barzon L, Sonino N, Fallo F, Palu G, Boscaro M. Prevalance and natural history of adrenal incidentalomas. Eur J Endocrinol, 2003;149(4):273-285.

14. Terzolo M, Pia A, Reimondo G. Subclinical Cushing's syndrome: definition and management. Clin Endocrinol (Oxf). 2012;76(1):12-18.

15. Bülow B, Ahrén B. Adrenal incidentaloma--experience of a standardized diagnostic programme in the Swedish prospective study. J Intern Med. 2002;252(3):239-46.

16. Reincke M. Subclinical Cushing's syndrome. Endocrinol Metab Clin North Am 2000;29(1):42-56.

17. Lee JM, Kim MK, Ko SH, Koh JM, Kim BY, Kim SW, et al. Clinical guidelines for the management of adrenal incidentaloma. Endocrinol Metab (Seoul). 2017;32(2):200-218

18. Cicala MV, Sartorato P, Mantero F. Incidentally discovered masses in hypertensive patients. Best Pract Res Clin Endocrinol Metab. 2006;20(3):451-66

19. Mannelli M, Ianni L, Cilotti A, Conti A. Pheochromocytoma in Italy: a multicentric retrospective study. Eur J Endocrinol. 1999;141(6):619-24.

20. Bernini G, Moretti A, Argenio G, Salvetti A. Primary aldosteronism in normokalemic patients with adrenal incidentalomas. Eur $\mathrm{J}$ Endocrinol. 2002;146(4):523-9.

21. Dunnick NR, Korobkin M. Imaging of adrenal incidentalomas: current status. American Journal of Roentgenology 2002;179:559-568.

22. Quayle FJ, Spitler JA, Pierce RA, Lairmore TC, Moley JF, Brunt LM. Needle biopsy of incidentally discovered adrenal masses is rarely informative and potentially hazardous. Surgery. 2007;142(4):497-502.

23. Sturgeon C, Shen WT, Clark OH, Duh QY, Kebebew E. Risk assessment in 457 adrenal cortical carcinomas: how much does tumor size predict the likelihood of malignancy? J Am Coll Surg. 2006;202(3):423-30.

24. Dackiw AP, Lee JE, Gagel RF, Evans DB. Adrenal cortical carcinoma. World J Surg. 2001;25(7):914-26.

25. Zeiger MA, Thompson GB, Duh QY, Hamrahian AH, Angelos P, Elaraj D, et al. The American Association of Clinical Endocrinologists and American Association of Endocrine Surgeons medical guidelines for the management of adrenal incidentalomas. Endocr Pract. 2009;15 Suppl 1:1-20.

26. Bernini GP, Moretti A, Oriandini C, Bardini M, Taurino C, Salvetti A. Long-term morphological and hormonal follow-up in a single unit on 115 patients with adrenal incidentalomas. Br J Cancer. 2005;92(6):1104-9.

27. Zeiger MA, Siegelman SS, Hamrahian AH. Medical and surgical evaluation and treatment of adrenal incidentalomas. J Clin Endocrinol Metab. 2011;96(7):2004-15.

28. Giordano R, Marinazzo E, Berardelli R, Picu A, Maccario M, Ghigo E, Arvat E. Long-term morphological, hormonal, and clinical followup in a single unit on 118 patients with adrenal incidentalomas. Eur J Endocrinol. 2010;162(4):779-85.

29. Bülow B, Jansson S, Juhlin C, Steen L, Thoren M, Wahrenberg H, et al. Adrenal incidentaloma-follow-up results from a Swedish prospective study. Eur J Endocrinol. 2006;154(3):419-23.

30. Ferrari M, Mantero F. Male aging and hormones: the adrenal cortex. J Endocrinol Invest. 2005;28 (11 Suppl Proceedings):92-5.

31. Libè R, Dall'asta C, Barbetta L, Baccarelli A, Beck-peccoz P, Ambrosi B. Long-term follow-up study of patients with adrenal incidentalomas. Eur J Endocrinol. 2002;147(4):489-94

32. Kaltsas G, Chrisoulidou A, Piaditis G, Kassi E, Chrousos G. Current status and controversies in adrenal incidentalomas. Trends Endocrinol Metab. 2012;23(12):602-9. 